\title{
Potentiation of cytokine induced iNOS expression in the human intestinal epithelial cell line, DLD-1, by cyclic AMP
}

M Cavicchi, B J R Whittle

\begin{abstract}
Background-Nitric oxide production by the inducible isoform of nitric oxide synthase (iNOS) is thought to play a role in the pathogenesis of inflammatory bowel disease along with other proinflammatory mediators.

Aims-To examine the effects of cAMP, an intracellular mediator of several proinflammatory mediators, on iNOS expression in the human intestinal epithelial cell line, DLD-1.

Methods-iNOS activity was assessed by measuring the NO stable oxidative product $\mathrm{NO}_{2}^{-}$. iNOS protein expression and iNOS mRNA levels were determined by western blotting and northern blotting, respectively.
\end{abstract}

Results-iNOS activity, protein, and mRNA were induced by a combination of interleukin $1 \beta(0.5-5 \mathrm{ng} / \mathrm{ml})$, interferon $\gamma$ (20-200 u/ml), and tumour necrosis factor $\alpha$ (10-100 ng/ml). The cytokine induced NOS activity was potentiated by $\mathrm{N}^{6}, 2^{\prime}-\mathrm{O}-$ dibutyryladenosine $3^{\prime}: 5^{\prime}$-cyclic monophosphate and 8-bromoadenosine 3':5'-cyclic monophosphate (0.1-1 $\mathrm{mM})$, and the adenylate cyclase activator, forskolin (1-100 $\mu M)$. This activity was inhibited by the selective iNOS inhibitor, 1400W (0.1-100 $\mu M)$. These agents increased iNOS protein. The cAMP analogues potentiated iNOS at the transcriptional level as shown by effects of actinomycin $D(5 \mu \mathrm{g} / \mathrm{ml})$ and northern blot analyses; the nuclear factor (NF) кB inhibitor, pyrrolidine dithiocarbamate (10$200 \mu M)$, significantly reduced this potentiation. The cAMP potentiated iNOS activity was inhibited by the tyrosine kinase inhibitor, A25 (10-200 $\mu M)$ and the Janus activated kinase 2 inhibitor, B42 (10-200 $\boldsymbol{\mu M})$.

Conclusions-Increased intracellular cAMP is a potent stimulus of iNOS expression in combination with cytokines in DLD-1 cells, acting at the transcriptional level and involving $N F-\kappa B$ and the JAK-STAT pathways. Thus, proinflammatory mediators that increase cAMP levels may augment iNOS expression and NO production.

(Gut 1999;45:367-374)

Keywords: inducible nitric oxide synthase colonic epithelial cells; nuclear factor $\kappa \mathrm{B}$; cytokines; cyclic AMP; JAK-2
The inducible isoform of nitric oxide synthase (iNOS) (EC 1.14.13.39) is capable of sustained production of high quantities of nitric oxide (NO), which is thought to be cytotoxic and to mediate deleterious effects. The iNOS isoform is expressed in a wide range of cells, mainly following exposure to cytokines and lipopolysaccharides.

The expression of iNOS and the NO produced or its subsequent products could play a key role in the pathogenesis of inflammatory bowel disease (IBD). Indeed, overexpression of iNOS protein, ${ }^{2-4}$ increased iNOS activity or NO release, ${ }^{5-8}$ and increased iNOS mRNA level, ${ }^{9}$ both in ulcerative colitis and in Crohn's disease, have been shown. Furthermore, besides macrophages and polymorphonuclear cells infiltrating mucosa and submucosa, intestinal and colonic epithelial cells represent a major source of NO during inflammatory processes including IBD. ${ }^{210-12}$

The nitric oxide pathway is known to interact with other systems, which are likely to be involved in the pathogenesis of IBD such as cyclooxygenase 2 (COX-2) and the adenosine $3^{\prime}: 5^{\prime}$-cyclic monophosphate (cAMP) pathways. ${ }^{13}$ COX-2 mRNA levels are increased in acute $\mathrm{IBD}^{14}$ and COX-2 protein is overexpressed along with iNOS in the colonic and intestinal epithelial cells of patients with IBD. ${ }^{15}$ Furthermore, the products of COX-2 enzyme activity, such as prostaglandin $\mathrm{E}_{2}$, have also been reported to be augmented in IBD. ${ }^{16}$ Cyclic AMP is thought to be the main intracellular mediator of proinflammatory prostaglandins through adenylate cyclase activation and could also mediate some effects of proinflammatory cytokines such as interferon $\gamma(\mathrm{IFN}-\gamma)$ and interleukin $1 \beta$ (IL-1 $\beta$ ) in macrophages and vascular smooth muscle cells. ${ }^{17}{ }^{18}$ It is noteworthy that increased colonic adenylate cyclase activity has been shown in tissue from ulcerative colitis. ${ }^{19}$ In addi-

Abbreviations used in this paper: $8 \mathrm{Br}-\mathrm{cAMP}$, 8-bromoadenosine 3':5'-cyclic monophosphate; 8Br-cGMP, 8-bromoguanosine 3':5'-cyclic monophosphate; cAMP, adenosine 3':5'-cyclic monophosphate; COX-2, cyclooxygenase 2; Db-cAMP, N ${ }^{6}, 2^{\prime}$-O-dibutyryladenosine 3':5'-cyclic monophosphate; DMEM, Dulbecco modified Eagle's medium; DMSO, dimethylsulphoxide; IBD, inflammatory bowel disease; IBMX, 3-isobutyl-1-methylxanthine; IFN, interferon; IL-1 $\beta$, interleukin $1 \beta$; iNOS, inducible nitric oxide synthase; JAK-2, Janus activated kinase 2 ; NF- $\mathrm{kB}$, nuclear factor $\kappa \mathrm{B} ; \mathrm{NO}$, nitric oxide; PBS, phosphate buffered saline; PDTC, pyrrolidine dithiocarbamate; TNF, tumour necrosis factor; CREB, cAMP responsive element binding protein; PKA, protein kinase A; ATF, activating transcription factor. 
tion, elevation of cAMP is thought to be responsible for secretory effects resulting in the diarrhoea observed in infectious enterocolitis ${ }^{2021}$ and possibly in IBD. ${ }^{22}$

In many cell types, the induction of iNOS can be modulated by cAMP. Indeed, cAMP has been shown to induce iNOS either alone or in combination with cytokines in mesangial cells, ${ }^{23}$ fibroblasts, ${ }^{24}$ vascular smooth muscular cells, ${ }^{25}$ macrophages, ${ }^{26}$ and cardiac myocytes. ${ }^{27}$ However, other reports suggest that cAMP may also act as an inhibitor of iNOS induction either in these same cell types, including macrophages and mesangial cells, ${ }^{28}$ or in insulinoma cells, hepatocytes, Kupffer cells, or glial cells. ${ }^{29-32}$

In human DLD-1 intestinal epithelial cells, iNOS can be induced by a combination of cytokines. ${ }^{33}{ }^{34}$ This expression is controlled mainly at the transcriptional level and involves a tyrosine protein kinase pathway ${ }^{35}$ and the pleiotropic transcription factor, nuclear factor $\kappa \mathrm{B}(\mathrm{NF}-\kappa \mathrm{B}) .^{37}{ }^{38}$ In the present study, the effects of cAMP on iNOS expression in the human epithelial intestinal cell line, DLD-1, have been investigated.

\section{Material and methods}

CELL CULTURE

The DLD-1 cell line was obtained from the European Collection of Cell Culture (Salisbury, UK) (No. 90102540) and used between passages 25 and 50 . Cells were grown in Dulbecco modified Eagle's medium (DMEM) with $4 \mathrm{mM}$ L-glutamine and $10 \%$ heat inactivated fetal calf serum. Cells were cultured at $37^{\circ} \mathrm{C}$ in a water saturated atmosphere of $95 \%$ air and $5 \% \mathrm{CO}_{2}$, refed every two days and passaged weekly. Cells were allowed to grow for 72-96 hours to confluence before use. Cytokines and other agents were added to fresh medium without serum. Cytokines used for induction were IFN- $\gamma$, IL- $1 \beta$, and tumour necrosis factor $\alpha(\mathrm{TNF}-\alpha)$.

CELL VIABILITY MEASUREMENT

Mitochondrial respiration, an indicator of cell viability, was assessed by the mitochondrial dependent reduction of MTT (3-(4,5dimethylthiazol-2-yl)-2,5-diphenyltetrazolium bromide) to formazan. Cells grown in 96 well plates were incubated at $37^{\circ} \mathrm{C}$ for one hour with $0.4 \mathrm{mM}$ MTT. Cells were solubilised in $100 \mu \mathrm{l}$ dimethyl sulphoxide and absorbance was read at $\lambda=550 \mathrm{~nm}$. Results were expressed as percentage of control (nontreated cells).

CELL COUNTING AND PROTEIN CONCENTRATION Cells were dissociated in a solution of $0.25 \%$ trypsin and $3 \mathrm{mM}$ EDTA in phosphate buffered saline (PBS) pH 7.4 (without calcium and magnesium). After five minutes cells were counted with a haemocytometer, adding trypan blue. Only cells that excluded dye were counted as viable cells. Results were expressed as number of viable cells per $\mathrm{ml}$. The protein concentration was determined using a modification of the Bradford method (Biorad kit) and bovine serum albumin as a standard. Results were expressed as $\mathrm{mg}$ of protein per $\mathrm{ml}$.

\section{ASSESSMENT OF NOS ACTIVITY}

Cells were stimulated in 96 well plates as indicated above. After 24 hours' exposure, cell culture medium was used to determine nitrite/ nitrate production as an index of NOS activity. To reduce nitrate $\left(\mathrm{NO}_{2}^{-}\right), 50 \mu \mathrm{l}$ of medium was transferred in a 96 well plate and incubated for 15 minutes at $37^{\circ} \mathrm{C}$ with flavin adenine dinucleotide $(50 \mu \mathrm{M}), \beta$-nicotinamide adenine dinucleotide phosphate, reduced form (500 $\mu \mathrm{M})$, and nitrate reductase from Aspergillus species $(1 \mathrm{U} / \mathrm{ml})$, and then five minutes further with lactic dehydrogenase $(100 \mathrm{U} / \mathrm{ml})$ and sodium pyruvate $(100 \mathrm{mM})$. Then, $50 \mu \mathrm{l}$ of Griess reagent $(0.25 \mathrm{M}$ phosphoric acid, 30 $\mathrm{mM}$ sulphanilamide, $2 \mathrm{mM}$ naphthylethylene diamine) was added to each well. The resultant colour change was quantified by spectrophotometry $(\lambda=550-650 \mathrm{~nm})$. Nitrate levels were determined using a sodium nitrate standard curve and expressed as $\mu \mathrm{M} / 10^{6}$ cells according to the cell number in each well.

WESTERN BLOTTING

Cells were washed with ice cold PBS ( $\mathrm{pH} 7.4$ ) and homogenised in Tris-mannitol buffer (2 $\mathrm{mM}$ Tris 7-9, $50 \mathrm{mM}$ mannitol, $100 \mu \mathrm{M}$ phenyl methyl sulphonyl fluoride, $2 \mu \mathrm{M}$ leupeptin, $0.5 \mathrm{mU} / \mathrm{ml}$ aprotinin, $0.5 \%$ Triton X-100), using a glass/glass homogeniser. Homogenates were sonicated twice for 10 seconds on ice and spun for 15 minutes at $21000 \mathrm{~g}$ at $4^{\circ} \mathrm{C}$. Aliquots of $100 \mu \mathrm{g}$ of total cellular protein were denatured by mixing and boiling v/v with 20 $\mathrm{mM}$ Tris 7-9, $2 \mathrm{mM}$ EDTA, $2 \%$ sodium dodecyl sulphate (SDS), $10 \% \beta$ mercaptoethanol, $20 \%$ glycerol. The samples were electrophoresed on $7.5 \%$ SDS-polyacrylamide gel, and then transferred to nitrocellulose membrane (Amersham, Little Chalfont, UK). After blocking with PBS (pH 7.4), 0.25\% Tween 20 $(\mathrm{v} / \mathrm{v})$, and $5 \%$ non-fat dried milk, membranes were probed with anti-iNOS monoclonal antibody at a 1/2000 dilution (Transduction Laboratories, Lexington, UK) for one hour at room temperature, washed with PBS-Tween 20, and then incubated with horseradish peroxidase conjugated second antibody (1/4000 dilution) for one hour at room temperature. Membranes were developed, using an enhanced chemiluminescence system (Amersham) and exposed to Hyperfilm (Amersham). Films were analysed using the Molecular Analyst Software (BioRad Laboratories, Hercules, USA) after scanning on a densitometer (GS-700 Imaging Densitometer, BioRad Laboratories).

\section{NORTHERN BLOTTING}

The iNOS cDNA probe was obtained by polymerase chain reaction (PCR) amplification of iNOS RNA from cytokine induced DLD-1 cells. The following primers were used to amplify the 3590-3848 bp region of human iNOS cDNA according to the published sequence (GenBank accession number: L09210), leading to a 259 bp fragment: 5'CGG TGC TGT ATT TCC TTA CGA GGC 
GAA GAA GG and 5'- GGT GCT GCT TGT TAG GAG GTC AAG TAA AGG GC. Then, the positive band was excised from the agarose gel and cDNA purified using a commercially available kit (Geneclean kit, Bio 101 Inc., La Jolla, California, USA).

Total RNA from cell monolayers was extracted using Trizol (Gibco BRL, Paisley, Scotland, UK). The amount of RNA was calculated from optical density measurements at $\lambda=260 \mathrm{~nm}$. A $10 \mu \mathrm{g}$ aliquot of total RNA was loaded on a $1 \%$ denaturing agarose gel, containing $2 \mathrm{M}$ formaldehyde and $6 \mathrm{mM} 3(\mathrm{~N}-$ morpholino)propanesulphonic acid. RNA was transferred onto an uncharged nylon membrane followed by hybridisation (Stratagene QuikHyb hybridisation solution, Cambridge, UK). The iNOS cDNA was radiolabelled with ${ }^{32} \mathrm{P}$-dCTP by the random primer method (Multiprime DNA labelling system, Amersham). A photograph of agarose gel stained with ethidium bromide was taken as control of equivalent loading between lanes. Films were analysed as described for western blots.

\section{STATISTICAL ANALYSIS}

Data are shown as mean (SEM) of at least three independent experiments, each done in triplicate. Northern and western blots are shown as a representative photograph of three independent experiments. Statistical significance was assessed by Student's $t$ test where $\mathrm{p}<0.05$ was taken as significant.

\section{CHEMICALS}

The iNOS antibody was from Transduction Laboratories (Affiniti Research Products, Exeter, UK). Human TNF- $\alpha$ was from R\&D Systems (Abingdon, UK). Nitrate reductase was from Boehringer Mannheim (Lewes, UK). Methanol and ethanol were from BDH Laboratories Supplies (Lutterworth, UK). Bisacrylamide solution and protein assay kit were from BioRad Laboratories (Hertfordshire, UK). DMEM, non-essential amino acids, Trizol, and primers were obtained from Gibco

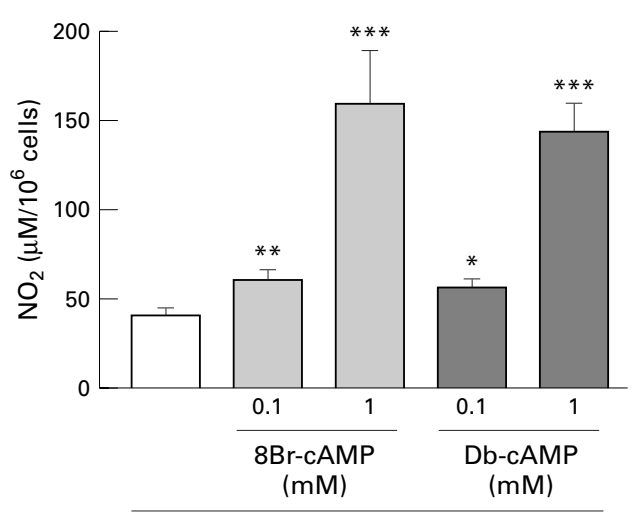

IFN $\gamma / \mathrm{IL}-1 \beta$

Figure 1 Potentiation of IFN- $\gamma / I L-1 \beta$ induced NOS activity by $8 B r-c A M P$ and $D b-c A M P$ in $D L D-1$ cells. Cells were incubated in serum free medium with a combination of IFN- $\gamma$ and IL-1 $\beta$ alone or with $8 B-c A M P$ or $D b-c A M P$. Results are expressed as means (SEM) from at least three different experiments, each done in triplicate. ${ }^{*} p<0.05,{ }^{*} p<0.01,{ }^{*} * x<0.001$ compared with value in the cells treated by IFN- $\gamma / I L-1 \beta$.
BRL (Paisley, UK). Tyrphostins A25 ( $\alpha$-cyano(3,4,5-trihydroxy)cinnamonitrile) and B42 (N-benzyl-3,4-dihydroxybenzylidenecyanoacetamide) were from Calbiochem (Nottingham, UK) and were prepared in dimethylsulphoxide, the final concentration of which did not exceed $0.2 \%$. Pyrrolidine dithiocarbamate (PDTC; Sigma, Poole, UK) was dissolved in phosphate buffered saline (PBS; pH 7.4). 1400W (N-(3(aminomethyl)benzyl)acetamidine) was a kind gift from Dr R Knowles (GlaxoWellcome Research, Stevenage, UK). All other compounds and chemicals were purchased from Sigma (Poole, UK).

\section{Results}

CYCLIC AMP EFFECTS ON NOS ACTIVITY

In DLD-1 cells, incubation with two cAMP analogues, $\mathrm{N}^{6}, 2^{\prime}-\mathrm{O}$-dibutyryladenosine $3^{\prime}: 5^{\prime}-$ cyclic monophosphate (Db-cAMP; $0.1-1 \mathrm{mM}$ ) or 8-bromoadenosine 3':5'-cyclic monophosphate (8Br-cAMP; $0.1-1 \mathrm{mM}$ ) alone caused no increase in $\mathrm{NO}_{2}^{-}$production compared with control cells. Thus, $\mathrm{NO}_{2}^{-}$levels were $0.8(0.3)$

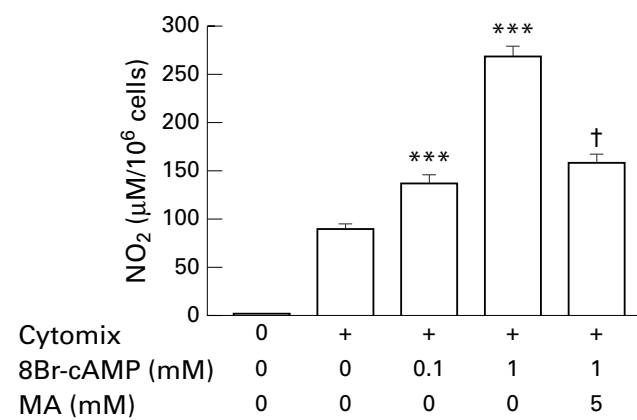

Figure 2 Potentiation of cytomix induced iNOS activity by $8 B r-c A M P$ was reversed by the $c A M P$ antagonist, 2'-O-methyl adenosine (MA), in DLD-1 cells. Cells were treated with vehicle alone or cytomix and coincubated with $8 B r-c A M P$ alone or MA. Results are expressed as means (SEM) from at least three different experiments, each done in triplicate. ${ }^{\star \star} p<0.001$ compared with value in the cells treated by cytomix alone; $t p<0.001$ compared with value obtained in the cells treated by cytomix and 8Br-cAMP.

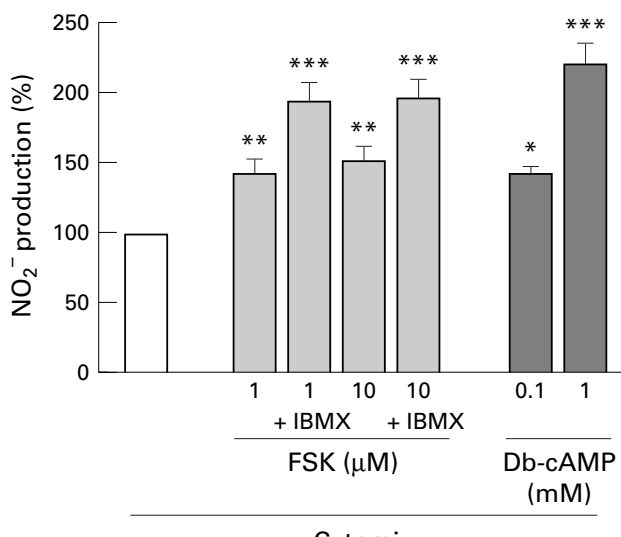

Cytomix

Figure 3 Potentiation of cytomix induced iNOS activity by forskolin (FSK) and Db-cAMP in DLD-1 cells. Cells were incubated in serum free medium with cytomix alone (white bars) or FSK, with or without

3-isobutyl-1-methylxanthine (IBMX) or Db-cAMP. Results are expressed as percentage of induction with cytomix alone and represent means (SEM) from at least three different experiments, each done in triplicate.

${ }^{*} p<0.05,{ }^{*} p<0.01,{ }^{*} \star_{p}<0.001$ compared with value obtained in cytomix treated cells. 
A

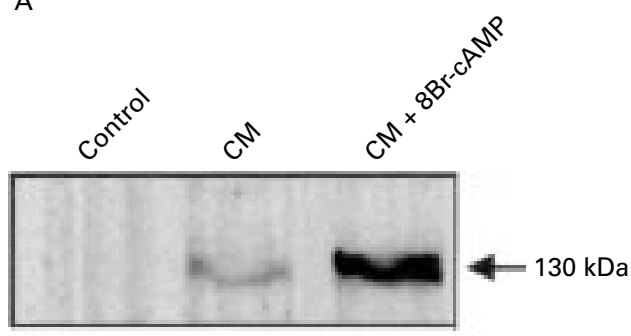

B

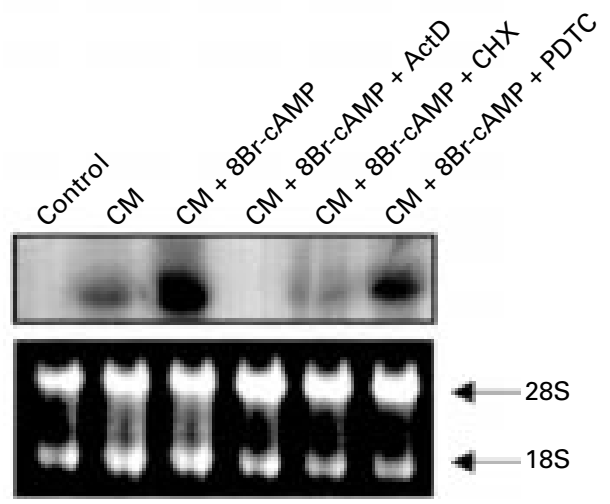

Figure 4 (A) iNOS protein expression in DLD-1 cells. Cells were treated for 12 hours with vehicle alone (control), cytomix (CM), and CM + 8Br-cAMP. This is a representative of three different experiments. (B) Transcriptional control of cAMP potentiation of $i N O S$ induction in DLD-1 cells. Cells were treated for six hours with vehicle alone, $C M, C M+8 B r-c A M P, C M+$ $8 B r-c A M P+$ actinomycin $D(A c t D), C M+8 B r-c A M P$ + cycloheximide $(C H X)$, and $C M+8 B r-c A M P+$ pyrrolidine dithiocarbamate (PDTC) (200 $\mu M$, two hours pretreatment). (Upper) Northern blot; (lower) ethidium bromide staining of $28 S$ and $18 S$ RNA bands indicating equal loading of the lanes. This is representative of three experiments.

$\mu \mathrm{M} / 10^{6}$ cells, $1.7(0.9) \mu \mathrm{M} / 10^{6}$ cells, and 0.85 (0.4) $\mu \mathrm{M} / 10^{6}$ cells in control cells, Db-cAMP $(1 \mathrm{mM})$ treated cells, and 8Br-cAMP $(1 \mathrm{mM})$ treated cells, respectively ( $\mathrm{p}>0.05)$.

A combination of IFN- $\gamma(200 \mathrm{u} / \mathrm{ml})$ and IL-1 $\beta$ ( $5 \mathrm{ng} / \mathrm{ml})$ for 24 hours increased $\mathrm{NO}_{2}{ }^{-}$ levels to 41.4 (3.1) $\mu \mathrm{M} / 10^{6}$ cells. Coincubation with Db-cAMP (0.1-1 $\mathrm{mM})$ and 8Br-cAMP $(0.1-1 \mathrm{mM})$ led to a dose dependent potentiation of the $\mathrm{NO}_{2}^{-}$production induced by the combination of these two cytokines (fig 1).

$8 \mathrm{Br}$-cAMP and Db-cAMP also increased the $\mathrm{NO}_{2}{ }^{-}$production induced by a combination of IL- $1 \beta$, IFN- $\gamma$, and TNF- $\alpha$ at low concentrations $(0.5 \mathrm{ng} / \mathrm{ml}, 20 \mathrm{u} / \mathrm{ml}$, and $10 \mathrm{ng} / \mathrm{ml}$, respectively). The latter mixture led to an $\mathrm{NO}_{2}{ }^{-}$ production of $36.3(8.3) \mu \mathrm{M} / 10^{6}$ cells, which was significantly increased to 106.2 (26.7) $\mu \mathrm{M} / 10^{6}$ cells and 170.5 (3.7) $\mu \mathrm{M} / 10^{6}$ cells with $1 \mathrm{mM} 8 \mathrm{Br}-\mathrm{cAMP}$ and $1 \mathrm{mM}$ Db-cAMP, respectively $(p<0.05$ and $p<0.001$, respectively).

8Br-cAMP and Db-cAMP also increased significantly the $\mathrm{NO}_{2}{ }^{-}$production provoked by incubation with the combination of the three cytokines for 24 hours at the higher concentrations, IFN- $\gamma(200 \mathrm{u} / \mathrm{ml}), \mathrm{IL}-1 \beta(5 \mathrm{ng} / \mathrm{ml})$, and $\mathrm{TNF}-\alpha(100 \mathrm{ng} / \mathrm{ml})$ (cytomix) as shown in figs 2 and 3.

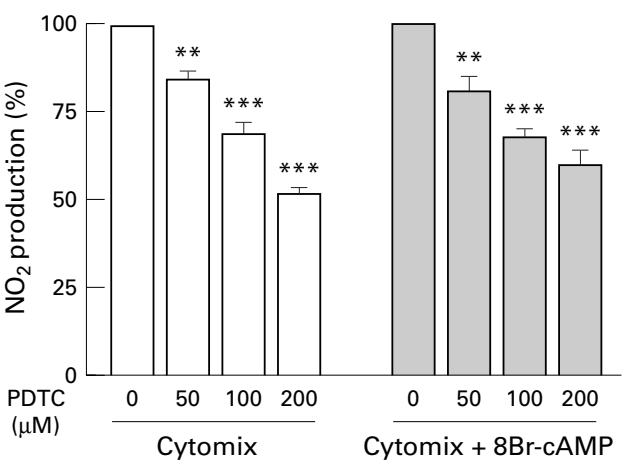

Figure 5 Dose dependent inhibition of cytomix induced and $c A M P$ potentiated $\mathrm{NO}_{2}^{-}$production by an $N F-\kappa B$ inhibitor in DLD-1 cells. Cells were treated in serum free medium for 24 hours with cytomix, alone or with $8 \mathrm{Br}-\mathrm{cAMP}$, and received two hours' pretreatment with increasing concentrations of pyrrolidine dithiocarbamate (PDTC). Results are expressed as percentage of maximal induction (without PDTC) and represent means (SEM) from at least three different experiments, each done in triplicate. ${ }^{\star *} p<0.01,{ }^{\star \star *} p<0.001$ compared with maximal induction.
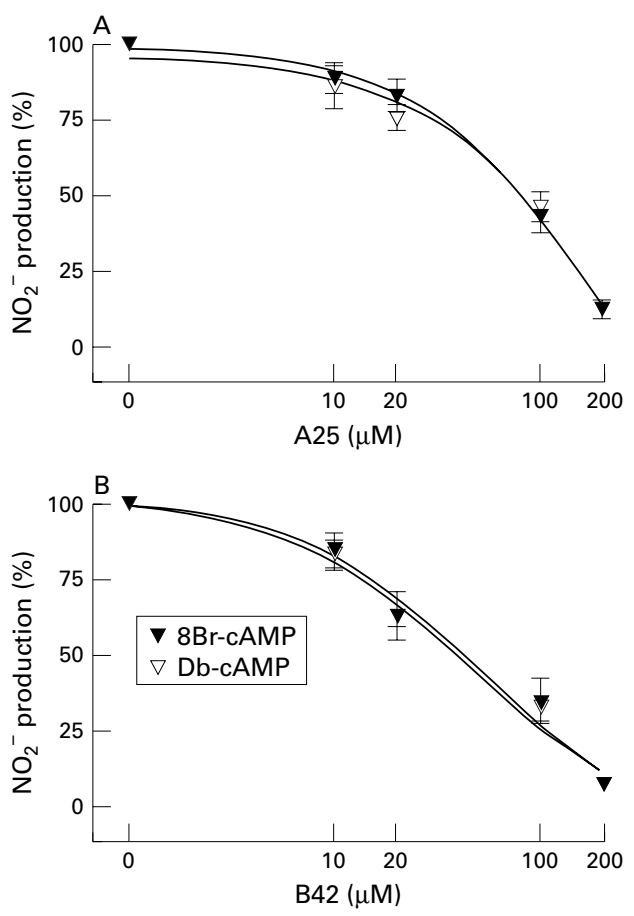

Figure 6 Inhibition of cAMP potentiated $\mathrm{NO}_{2}$ production by the tyrosine kinase inhibitor, tyrphostin $A 25$ $(A)$ and the $\mathcal{F A K - 2}$ inhibitor, tyrphostin $B 42(B)$ in DLD-1 cells. Cells were treated in serum free medium for 24 hours with cytomix and $8 B r-c A M P$ or $D b-c A M P$. Results are expressed as percentage of maximal induction (without tyrphostin) and represent means (SEM) from at least three different experiments, each done in triplicate.

The guanosine 3':5'-cyclic monophosphate analogue, $8 \mathrm{Br}-\mathrm{cGMP}(0.1-1 \mathrm{mM})$ had no effect on $\mathrm{NO}_{2}^{-}$production either when used alone or in combination with any cytokine mixture (100.7 (3.7)\% and 96.3 (8)\% of the cytomix induced $\mathrm{NO}_{2}^{-}$production with $8 \mathrm{Br}-$ cGMP 0.1 and $1 \mathrm{mM}$, respectively).

An activator of adenylate cyclase, forskolin $(1-100 \mu \mathrm{M})$, also significantly potentiated cytomix induced $\mathrm{NO}_{2}^{-}$production with a maximal effect at $10 \mu \mathrm{M}$ forskolin (fig 3). No further increase was observed at higher concentrations. No effect was observed with 


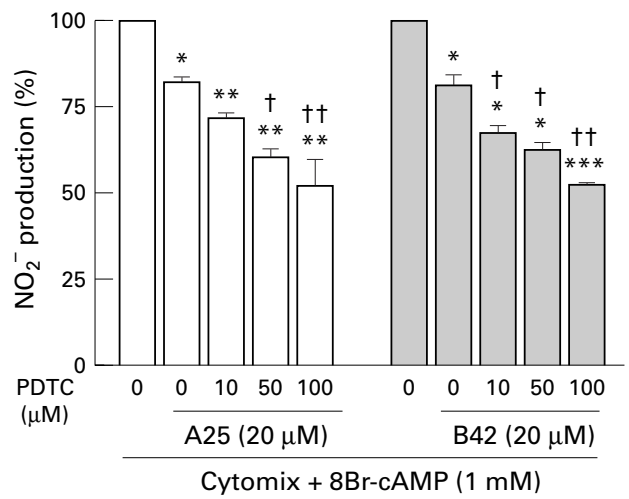

Figure 7 Effect of coincubation with the $N F-\kappa B$ inhibitor, pyrrolidine dithiocarbamate (PDTC) and tyrphostins $A 25$ or $B 42$ on cAMP potentiated $\mathrm{NO}_{2}^{-}$production in $D L D-1$ cells. Cells were treated in serum free medium for 24 hours with cytomix and $8 B r-c A M P$ with or without A25 or B42, and were then treated with increasing concentrations of PDTC. Results are expressed as percentage of maximal induction (without tyrphostin and PDTC) and represent means (SEM) from at least three different experiments, each done in triplicate. ${ }^{\star} p<0.05,{ }^{\star \star} p<0.01,{ }^{\star \star \star} p<0.001$, compared with maximal induction; $t p<0.05$, $t+p<0.01$, compared with value obtained in cells treated with A25 or B42.

forskolin in the absence of cytokine (1.2 (0.3) $\mu \mathrm{M} / 10^{6}$ cells with forskolin $10 \mu \mathrm{M} ; \mathrm{p}>0.05 \mathrm{com}-$ pared with control cells). The potentiation of cytomix induced $\mathrm{NO}_{2}^{-}$production by forskolin was further significantly augmented by coincubation with the phosphodiesterase inhibitor, 3-isobutyl-1-methylxanthine (IBMX; $100 \mu \mathrm{M}$ ) as shown in fig 3. IBMX did not increase $\mathrm{NO}_{2}{ }^{-}$ production when added to cytomix alone, being 121 (3) \% the $\mathrm{NO}_{2}^{-}$release provoked by cytomix alone.

Incubation with the cAMP antagonist, 2'-Omethyl adenosine $(5 \mathrm{mM})$, significantly reversed the $8 \mathrm{Br}$-cAMP and $\mathrm{Db}$-cAMP potentiation of cytomix induced $\mathrm{NO}_{2}^{-}$production (fig $2)$. In addition, 2 '-O-methyl adenosine $(5 \mathrm{mM})$ was also able to decrease by 35.5 (3.4)\% the $\mathrm{NO}_{2}{ }^{-}$production observed in cells treated with cytomix alone $(\mathrm{p}<0.01)$.

The cAMP potentiated $\mathrm{NO}_{2}^{-}$production was confirmed to be the result of iNOS expression, by its concentration dependent inhibition by the selective iNOS inhibitor, $1400 \mathrm{~W}$ $(0.1-100 \mu \mathrm{M})$, with an $\mathrm{IC}_{50}$ of $7.15(0.8) \mu \mathrm{M}$. Furthermore, western blot analyses using a monoclonal iNOS antibody showed increased iNOS protein expression in DLD-1 cells treated with $8 \mathrm{Br}$-cAMP $(1 \mathrm{mM})$ and cytomix compared with cells treated with cytomix alone (fig 4A).

Table 1 Effect of cAMP analogues on cell viability in DLD-1 cells exposed for 24 hours to cytomix (CM)

\begin{tabular}{lll}
\hline Cell treatment & Viable cells $\left(10^{6} / \mathrm{ml}\right)$ & MTT assay (\%) \\
\hline Control & $0.254(0.023)$ & 100 \\
CM & $0.246(0.033)$ & $104.5(2.7)$ \\
CM + 8Br-cAMP 0.1 mM & $0.203(0.022)^{\star \star}$ & $86.6(4)^{\star \star}$ \\
CM + 8Br-cAMP 1 mM & $0.151(0.009)^{\star \star \star}$ & $74.8(4.8)^{\star \star \star}$ \\
CM + Db-cAMP 0.1 mM & $0.213(0.005)^{\star \star}$ & $90.5(5.1)^{\star \star}$ \\
CM + Db-cAMP 1 mM & $0.185(0.012)^{\star \star \star}$ & $85.2(6)^{\star \star \star}$ \\
\hline
\end{tabular}

Results expressed as mean (SEM) from at least three different experiments. The number of viable cells was assessed by the trypan blue exclusion test. Statistical significance was assessed by Student's $t$ test.

${ }^{\star \star} \mathrm{p}<0.01,{ }^{\star \star \star} \mathrm{p}<0.001$ compared with control.
CYCLIC AMP EFFECTS ON iNOS MRNA

The iNOS mRNA was detected at six hours by northern blot analysis in cytomix treated DLD-1 cells but not in control vehicle treated cells. Following coincubation of the cells with cytomix and 8Br-cAMP (1 $\mathrm{mM}$ ), a further increase was observed varying from $140 \%$ to $170 \%$ by densitometric analyses (range from three experiments) compared with the level in the cytomix treated cells. Actinomycin D (5 $\mu \mathrm{g} / \mathrm{ml}$ ) abolished this signal (fig $4 \mathrm{~B}$ ). Treatment with actinomycin $\mathrm{D}(5 \mu \mathrm{g} / \mathrm{ml})$ also decreased the cAMP potentiated $\mathrm{NO}_{2}{ }^{-}$production, to 1.4 (0.8) $\mu \mathrm{M} / 10^{6}$ cells, reaching the basal level.

Pyrrolidine dithiocarbamate (PDTC, 10$200 \mu \mathrm{M})$ concentration dependently inhibited $8 \mathrm{Br}-\mathrm{cAMP}$ potentiated $\mathrm{NO}_{2}^{-}$production. Its effect was similar to that obtained in cells treated with cytomix alone and inhibited $\mathrm{NO}_{2}{ }^{-}$ production by 40.1 (3.5)\% at a concentration of $200 \mu \mathrm{M}$ (fig 5). The vehicle for PDTC (PBS) had no effect on cytokine induced $\mathrm{NO}_{2}^{-}$ production. The level of iNOS $\mathrm{mRNA}$ induced by $8 \mathrm{Br}-\mathrm{cAMP}$ and cytokines was decreased by $18.5(3.5) \%$ with PDTC $(200 \mu \mathrm{M})$ as shown in fig 4B. Cycloheximide $(5 \mu \mathrm{g} / \mathrm{ml})$ also substantially reduced this iNOS mRNA level as shown (fig 4B).

EFFECTS OF TYRPHOSTINS A25 AND B42 ON CAMP POTENTIATED iNOS ACTIVITY

The tyrphostins A25 (10-200 $\mu \mathrm{M})$ and B42 $(10-200 \mu \mathrm{M})$ were prepared in dimethylsulphoxide (DMSO). The maximal final concentration of DMSO was $0.2 \%$ and this concentration had no significant effect on cytomix induced $\mathrm{NO}_{2}^{-}$production $(96.1$ (5.1)\% of control, $\mathrm{n}=3$ ). The tyrphostins A25 and B42 had no effect on $\mathrm{NO}_{2}^{-}$production when incubated alone in resting cells. However, the tyrphostins A25 and B42 inhibited the $\mathrm{NO}_{2}{ }^{-}$ production caused by incubation with $8 \mathrm{Br}-$ cAMP $(1 \mathrm{mM})$ and cytomix in a dose dependent manner with $\mathrm{IC}_{50}$ values of 232 (58) $\mu \mathrm{M}$ and 32 (2.4) $\mu \mathrm{M}$ for A25 and B42, respectively. A similar effect was observed in cells treated by Db-cAMP (1 $\mathrm{mM}$ ) and cytomix with $\mathrm{IC}_{50}$ values of 240 (42) $\mu \mathrm{M}$ and 42 (6) $\mu \mathrm{M}$ for A25 and B42, respectively (fig 6 ). This inhibitory effect of A25 and B42 was not significantly different from that obtained in cells incubated with cytomix alone with $\mathrm{IC}_{50}$ values of 276 (20) $\mu \mathrm{M}$ and 37 (1) $\mu \mathrm{M}$ for A25 and B42, respectively.

Incubation of the cAMP/cytomix treated cells with PDTC $(10-100 \mu \mathrm{M})$ further augmented the inhibition of $\mathrm{NO}_{2}^{-}$production by A25 or B42 $(20 \mu \mathrm{M})$ (fig 7$)$.

CYCLIC AMP AND CELL VIABILITY

Dose dependent cytotoxicity was observed in cells treated with cytomix and $8 \mathrm{Br}$-cAMP or Db-cAMP, as estimated by the MTT assay and the trypan blue exclusion (table 1). Neither 1400W $(100 \mu \mathrm{M})$ nor 2'-O-methyl adenosine $(5 \mathrm{mM})$ reversed this toxicity (table 2$)$. Similar cytotoxicity was observed in cells treated with cAMP analogues alone. Forskolin was also cytotoxic to DLD-1, but only at the highest concentration, with a cell viability of 95 (2)\% 
Table 2 Effect of the cAMP antagonist, 2'-O-methyl adenosine $(M A)$ and of the iNOS selective inhibitor, $1400 \mathrm{~W}$ on cell toxicity provoked by $8 \mathrm{Br}-c \mathrm{AMP}$ in cells exposed for 24 hours to cytomix (CM)

\begin{tabular}{ll}
\hline Cell treatment & $\begin{array}{l}\text { MTT assay } \\
\text { (\% of control) }\end{array}$ \\
\hline $\mathrm{CM}+8 \mathrm{Br}-\mathrm{cAMP} 1 \mathrm{mM}$ & $74.8(4.8)$ \\
$\mathrm{CM}+8 \mathrm{Br}-\mathrm{cAMP} 1 \mathrm{mM}+\mathrm{MA}(5 \mathrm{mM})$ & $77.5(7.5)$ \\
$\mathrm{CM}+8 \mathrm{Br}-\mathrm{cAMP} 1 \mathrm{mM}+1400 \mathrm{~W}(100 \mu \mathrm{M})$ & $77.4(8.6)$ \\
\hline
\end{tabular}

Results expressed as mean (SEM) from at least three different experiments. There was no statistically significant difference (Student's $t$ test) between the three treatments.

with $10 \mu \mathrm{M}$ forskolin ( $\mathrm{p}>0.05$, compared with control) and 83 (5)\% with $50 \mu \mathrm{M}$ forskolin ( $\mathrm{p}<0.01$, compared with control), as determined by the MTT assay.

\section{Discussion}

In this study, using cAMP analogues, as well as the adenylate cyclase activator forskolin and the phosphodiesterase inhibitor, 3-isobutyl-1methylxanthine, we have shown that cAMP potentiates cytokine induced iNOS activity, protein, and mRNA in the human intestinal epithelial cell line, DLD-1. Cyclic AMP has been shown to induce iNOS expression in many cell types but the majority of these are rat cell lines. Indeed, cAMP responsive element (CRE) sites have been identified in the rat iNOS gene ${ }^{39}$ and could be involved in the iNOS expression caused by cAMP alone or in combination with cytokines. Nevertheless, cAMP can also decrease iNOS expression in cells of rat origin. $^{28} 3240$ To our knowledge, only two studies have reported cAMP enhancement of iNOS expression in human cells, these being monocytes and T cells. ${ }^{412}$ Thus, differences in cyclic AMP effects could reflect the cell and species specificity of iNOS gene regulation.

As shown by northern blot analyses and the effects of the transcription inhibitor, actinomycin $\mathrm{D}$ on iNOS activity and mRNA expression, this potentiation is mainly controlled at the transcriptional level. Increased intracellular concentrations of cAMP stimulate several pathways, including the protein kinase A (PKA) pathway. Within the nucleus, PKA phosphorylates the cAMP responsive element binding protein (CREB), enhancing its DNA binding activity. ${ }^{43}$ As there is no reported CRE binding sequence in the $5^{\prime}$ flanking region of the iNOS gene in DLD-1 cells, ${ }^{37}{ }^{38}$ cAMP potentiation of iNOS expression is unlikely to reflect a direct effect on the iNOS gene through the CREB/ATF (CREB/activating transcription factor) family of transcription factors. Nevertheless, cAMP and PKA pathways have been shown to be involved in the activation of some other transcription factors which are thought to play an important role in iNOS gene activation in DLD-1. Indeed, cAMP may induce iNOS gene transcription through activation of $N F-\kappa B$ directly ${ }^{44}$ or through PKA dependent phosphorylation of the I $\mathrm{KB}$ subunit. ${ }^{45}{ }^{46}$ Cyclic AMP, through activation of CREB, may also compete directly with AP- $1,{ }^{47}$ which has been recently reported to be a negative regulator of iNOS in DLD-1 cells. ${ }^{36}$

Recently, forskolin $(100 \mu \mathrm{M})$ and Db-cAMP $(100 \mu \mathrm{M})$, either alone or in combination with cytokine, have been reported to produce no increase in the iNOS mRNA level in DLD-1 cells. ${ }^{35}$ However, in the present study, forskolin was active at a concentration of $100 \mu \mathrm{M}$ but was less potent than at a concentration of $1 \mu \mathrm{M}$ and $10 \mu \mathrm{M}$. These effects of forskolin were further augmented in the presence of the phosphodiesterase inhibitor, 3-isobutyl-1-methylxanthine. Db-cAMP, which is considered resistant to phosphodiesterase activity, was only slightly effective at $100 \mu \mathrm{M}$ in our studies, the maximum potentiation being obtained with $1 \mathrm{mM}$ of the dibutyryl and 8Br-cAMP analogues. Others have also shown that only high concentrations of Db-cAMP (0.1-1 mM) are able to increase iNOS in rat mesangial cells. ${ }^{48}$ Nevertheless, the similar effect that we observed with two lipophilic cAMP analogues, as well as an adenylate cyclase activator, but not with a corresponding analogue of cyclic GMP, at the level of the iNOS mRNA, protein and activity suggest that cAMP has a role in iNOS modulation in DLD-1 cells.

The effect of the putative NF- $\mathrm{NB}$ inhibitor, PDTC, on $\mathrm{NO}_{2}{ }^{-}$production and iNOS $\mathrm{mRNA}$ levels suggests that cAMP potentiated iNOS transcription involves this transcription factor. These results are in agreement with previous reports of NF- $\kappa$ B involvement in DLD-1 after cytokine exposure. ${ }^{34}$ In contrast, recent reports, detecting mRNA only, suggest that this pathway is not a major effector of iNOS gene transcription in this cell type. ${ }^{36}$ In the present study, we could obtain only about $50 \%$ inhibition of iNOS activity and the level of the iNOS mRNA was hardly decreased with high concentrations of PDTC $(200 \mu \mathrm{M})$. However, the translation inhibitor, cycloheximide was able to reduce substantially the iNOS mRNA level after exposure to cAMP/cytokine. These findings support the suggestion that some other transcription factors could participate in iNOS gene transcription and/or that posttranscriptional events, such as mRNA stabilisation, could occur in regulating iNOS expression. ${ }^{34} 3638$

The IFN- $\gamma$ activated kinase JAK- 2 is known to tyrosine phosphorylate STAT $1 \alpha$, which is subsequently translocated into the nucleus to bind specific DNA sites. ${ }^{49}$ It has been recently proposed that the JAK-STAT pathway could play an important role in iNOS induction in DLD-1 cells. ${ }^{36}$ Our results confirm these findings, showing that the iNOS activity induced by cAMP/cytokine incubation was inhibited by the tyrosine kinase inhibitor A25 and by the specific JAK-2 inhibitor, B $42 .^{50}$ As abolition of iNOS activity was observed with B42, JAK-2 activation is strongly implicated in iNOS induction in DLD-1 cells. Nevertheless, our findings suggest that the STAT and $N F-\kappa B$ pathways are both involved in the cAMP/ cytokine iNOS induction in DLD-1 cells.

The potentiation of cytokine induced iNOS activity was inhibited by the cAMP antagonist, 2'-O-methyl adenosine, suggesting specific interactions with cAMP receptors. Furthermore, the iNOS activity provoked by cytomix alone was also partially inhibited by 2'-O-methyl adenosine. This result suggests that induction of 
iNOS by cytokines is partly modulated by the endogenous cAMP in DLD-1 cells, as reported in non-intestinal cell types with IL-1 $\beta$ or IFN- $\gamma .{ }^{17} 1846$

In the present work, the cAMP analogues were cytotoxic to DLD-1 cells following 24 hours incubation. NO production or iNOS activation are unlikely to be involved as the cAMP analogues were equally toxic with or without cytokine. Furthermore, the selective iNOS inhibitor, $1400 \mathrm{~W}$ did not attenuate this toxicity in concentrations that inhibited the iNOS activity induced by cytomix. The decrease in cell viability is unlikely to be directly related to the intracellular increase in cAMP concentration, as the cAMP antagonist, 2'-Omethyl adenosine did not modify this cytotoxicity and the mechanism of this action is therefore unknown.

These results emphasise the possible relation between the iNOS pathway and other proinflammatory mediators that act through cAMP mediated pathways. Such findings support the concept that cAMP may act as an important intracellular mediator in inflammation, ${ }^{51}$ being additionally involved in the regulation of iNOS expression provoked by cytokines in intestinal or colonic epithelial cells.

The authors are indebted to Ms Elizabeth Wood for supplying the cultured cells. They would like to acknowledge Dr Linda Gibbs for her help in performing northern blot analyses. MC is dies de l'Appareil Digem Institut

1 Knowles RG, Moncada S. Nitric oxide synthases in mammals Biochem f 1994:298:249-58.

2 Singer II, Kawka DW, Scott S, et al. Expression of inducible nitric oxide synthase and nitrotyrosine in colonic epithelium in inflammatory bowel disease. Gastroenterology 1996, 111:871-85.

3 Godkin AJ, De Belder AJ, Villa L, et al. Expression of nitric oxide synthase in ulcerative colitis. Eur $\mathcal{F}$ Clin Invest 1996;26:867-72.

4 Ikeda I, Kasajima T, Ishiyama S, et al. Distribution of inducible nitric oxide synthase in ulcerative colitis. Am $\mathcal{F}$ Gastroenterol 1997;92:1339-41.

5 Boughton-Smith NK, Evans SM, Hawkey CJ, et al. Nitric oxide synthase activity in ulcerative colitis and Crohn's disease. Lancet 1993;342:338-40.

6 Rachmilewitz D, Stamler JS, Bachwich D, et al. Enhanced colonic nitric oxide generation and nitric oxide synthase activity in $36: 718-23$.

7 Kimura H, Miura S, Shigematsu T, et al. Increased nitric oxide production and inducible nitric oxide synthase activity in colonic mucosa of patients with active ulcerative colitis and Crohn's disease. Dig Dis Sci 1997;42:1047-54.

8 Oudkerk Pool M, Bouma G, Visser JJ, et al. Serum nitrate levels in ulcerative colitis and Crohn's disease. Scand $\mathcal{F}$ Gastroenterol 1995;30:784-8.

9 Mclaughlan JM, Seth R, Vautier G, et al. Interleukin-8 and inducible nitric oxide synthase mRNA levels in inflammatory bowel disease at first presentation. F Pathol 1997;181: 87-92.

10 Kolios G, Rooney N, Murphy CT, et al. Expression of inducible nitric oxide synthase activity in human colon epithelial cells: modulation by $\mathrm{T}$ lymphocyte derived cythelial cells: modulation by

11 Tepperman BL, Brown JF, Whittle BJR. Nitric oxide synthase induction and intestinal cell viability in rats. $A m \mathcal{F}$ Physiol 1993;265:G214-18.

12 Cook HT, Bune J, Jansen AS, et al. Cellular localization of inducible nitric oxide synthase in experimental endotoxic shock in the rat. Clin Sci 1994;87:179-86.

$13 \mathrm{Wu} \mathrm{KK}$. Inducible cyclooxygenase and nitric oxide synthase. Adv Pharmacol 1995;33:179-207.

14 Hendel J, Nielsen OH. Expression of cyclooxygenase-2 mRNA in active inflammatory bowel disease. Am f Gastroenterol 1997;92:1170-3.

15 Singer II, Kawka DW, Schloemann S, et al. Cyclooxygenase 2 is induced in colonic epithelial cells in inflammatory bowel disease. Gastroenterology 1998;115:297-306.

16 Lauritsen K, Laursen LS, Bukhave K, et al. Effects of topical 5-aminosalicylic acid and prednisolone on prostaglandin $\mathrm{E}_{2}$ and leukotriene $\mathrm{B}_{4}$ levels determined by equilibglandin $\mathrm{E}_{2}$ and leukotriene $\mathrm{B}_{4}$ levels determined by equilib-
rium in vivo dialysis of rectum in relapsing ulcerative rium in vivo dialysis of rectum in relaps
colitis. Gastroenterology 1986;91:837-44.
17 Coffey RG, Yamamoto Y, Snella E, et al. Tetrahydrocannabinol inhibition of macrophage nitric oxide production. Biochem Pharmacol 1996;52:743-51.

18 Boese M, Busse R, Mülsch A, et al. Effect of cyclic GMP-dependent vasodilators on the expression of inducible nitric oxide synthase in vascular smooth muscle cells: role of cyclic AMP. Br F Pharmacol 1996;119:707-15.

19 Rachmilewitz D, Karmeli F, Selinger Z. Increased colonic adenylate cyclase activity in active ulcerative colitis. Gastroenterology 1983;85:12-16.

20 Everest PH, Cole AT, Hawkey CJ, et al. Roles of leukotriene B4, prostaglandin E2, and cyclic AMP in Campylobacter jejuni-induced intestinal fluid secretion. Infect Immun 1993;61:4885-7.

21 Peterson JW, Lu Y, Duncan J, et al. Interactions of intestinal mediators in the mode of action of cholera toxin. $7 \mathrm{Med}$ Microbiol 1994;41:3-9.

22 Bode H, Schmitz H, Fromm M, et al. IL-1beta and TNF-alpha, but not IFN-alpha, IFN-gamma, IL-6 or IL-8, are secretory mediators in human distal colon. Cytokines 1998;10:457-65.

23 Kunz D, Mühl G, Walker G, et al. Two distinct signaling pathways trigger the expression of inducible nitric oxide synthase in rat mesangial renal cells. Proc Natl Acad Sci USA 1994;91:5387-91.

24 Gilbert RS, Herschman HRJ. "Macrophage" nitric oxide synthase is a glucocorticoid-inhibitable primary response gene in 3T3 cells. 7 Cell Physiol 1993;157:128-32.

25 Koide M, Kahawara Y, Nakayama I, et al. Cyclic AMP-elevating agents induce an inducible type of nitric oxide synthase in cultured vascular smooth muscle cells. Synergism with the induction elicited by inflammatory cytokines. F Biol Chem 1993;268:24959-66.

26 Mavel J, Ransijn A, Corradin SB, et al. Effects of $\mathrm{PGE}_{2}$ and of agents that raise cAMP levels on macrophage activation induced by INF-gamma and TNF-alpha. $\mathcal{f}$ Leukoc Biol 1995;58:217-24.

27 Kinugawa K, Shimizu T, Yao A, et al. Transcriptional regulation of inducible nitric oxide synthase in cultured neonatal rat cardiac myocytes. Circ Res 1997;81:911-21.

28 Pang L, Hoult JRS. Repression of inducible nitric oxide synthase and cyclooxygenase- 2 by prostaglandin $\mathrm{E}_{2}$ and other cyclic AMP stimulants in J774 macrophages. Biochem Pharmacol 1997;53:493-500.

29 Messmer UK, Brune B. Modulation of inducible nitric oxide synthase in RINm5F cells. Cell Signal 1994;6:17-24.

30 Minghetti L, Nicoloni A, Polazzi E, et al. Prostaglandin $\mathrm{E}_{2}$ downregulates inducible nitric oxide synthase expression in microglia by increasing cAMP levels. Adv Exp Med Biol 1997;433:181-4.

31 Smith FS, Ceppi ED, Titheradge MA. Inhibition of cytokine-induced inducible nitric oxide synthase expression by glucagon and cAMP in cultured hepatocytes. Biochem $\mathcal{f} 1997 ; 326: 187-92$.

32 Mustafa SB, Olson MS. Expression of nitric oxide synthase in rat Kupffer cells is regulated by cAMP. $\mathcal{F}$ Biol Chem 1998;273:5073-80.

33 Sherman PA, Laubach VE, Reep BR, et al. Purification and DNA sequence of an inducible nitric oxide synthase from a human tumor cell line. Biochemistry 1993;32:11600-5.

34 Salzman AL, Denenberg AG, Ueta I, et al. Induction and activity of nitric oxide synthase in cultured human intestinal epithelial monolayers. Am $\mathcal{F}$ Physiol 1996;270:G565-73.

35 Kleinert $\mathrm{H}$, Wallerath T, Fritz G, et al. Cytokine induction of NO synthase II in human DLD-1 cells: roles of the Pharmacol $1998 ; 125: 193-201$.

36 Kleinert H, Euchenhofer C, Fritz G, et al. Involvement of protein kinases in the induction of NO synthase II in protein kinases in the induction of NO synthase II in

37 Nunokawa Y, Oikawa S, Tanaka S. Human inducible nitric oxide synthase gene is transcriptionally regulated by nuclear factor- $\mathrm{kB}$ dependent mechanism. Biochem Biophys Res Commun 1996;223:347-52.

38 Linn SC, Morelli PJ, Edry I, et al. Transcriptional regulation of human inducible nitric oxide synthase gene in an intestinal epithelial cell line. Am f Physiol 1997;35:G1499-508.

39 Eberhardt W, Pluss C, Hummel R, et al. Molecular mechanisms of inducible nitric oxide synthase gene expression by IL-1 beta and cAMP in rat mesangial cells. F Immunol 1998;160:4961-9.

40 Feinstein DL, Galea E, Reis DJ. Norepinephrine suppresses inducible nitric oxide synthase activity in rat astroglial cultures. F Neurochem 1993;60:1945-8.

tures. F Neurochem 1993;60:1945-8.
41 Aymerich MS, Bengoechea-Alonso MT, Lopez-Zabalza MJ,

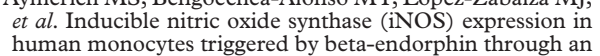
increase in cAMP. Biochem Biophys Res Commun 1998;245: increase in $717-21$.

42 Benbernou N, Esnault S, Shin HC, et al. Differential regulation of IFN-gamma, IL-10 and inducible nitric oxide synthase in human $\mathrm{T}$ cells by cyclic AMP-dependent signal transduction pathway. Immunology 1997;91:361-8.

43 Gonzalez GA, Montminy MR. Cyclic AMP stimulates somatostatin gene transcription by phosphorylation of CREB at serine 133. Cell 1989;59:675-80.

44 Serkkola E, Hurme M. Activation of NF-kappa B by cAMP in human myeloid cells. FEBS Lett 1993;334:327-30

45 Muroi M, Suzuki T. Role of protein kinase A in LPS-induced activation of NF-kappaB proteins of a mouse macrophagesactivation of NF-kappaB proteins of a mouse

46 Jeon YJ, Yang KH, Pulaski JT, et al. Attenuation of inducible nitric oxide synthase gene expression by $\Delta^{9}-$ 

tetrahydrocannabinol is mediated through the inhibition of nuclear

47 Masquilier D, Sassone-Corsi P. Transcriptional cross-talk: nuclear factors CREM and CREB bind to AP-1 sites and inhibit activation by Jun. I Biol Chem 1992;267:22460-6. 48 Nüsing RM, Klein T, Pfeilshifter J, et al. Effect of cyclic $A M P$ and prostaglandin $E_{2}$ on the induction of nitric oxide and prostanoid-forming pathways in cultured rat mesangial cells. Biochem f 1996;313:617-23.
49 Weber-Nordt RM, Mertelsmann R, Finke J. The JAKSTAT pathway: signal transduction involved in proliferation, differentiation and transformation. Leuk Lymphoma 1998;28:459-67.

50 Meydan N, Grunberger T, Dadi H, et al. Inhibition of acute lymphoblastic leukaemia by a Jak-2 inhibitor. Nature 1996; 379:645-8.

51 Moore AR, Willoughby DA. The role of cAMP regulation in controlling inflammation. Clin Exp Immunol 1995;101: $387-9$. 